\title{
Ontogenetic radular variation in species of Tambja Burn, 1962 (Gastropoda, Opisthobranchia, Polyceratidae), from the eastern Atlantic Ocean and the Mediterranean Sea*
}

\author{
AMELIA OCAÑA ${ }^{1}$, LUIS SÁNCHEZ-TOCINO ${ }^{1}$ and FRANCISCO J. GARCÍA ${ }^{2}$ \\ ${ }^{1}$ Depto. Biología Animal y Ecología; Facultad de Ciencias; Universidad de Granada; Avda. Fuentenueva s/n; \\ 18071 Granada; Spain. E-mail:amelia@ugr.es; 1stocino@ugr.es \\ ${ }^{2}$ Depto. Fisiología y Biología Animal; Facultad Biología; Univ. Sevilla; Apdo.1095; Avda Reina Mercedes, 6; \\ 41080 Sevilla; Spain. E-mail: fjgarcia@us.es
}

\begin{abstract}
SUMMARY: Of the 10 species in the genus Tambja (Polyceratidae) described in the biogeographical Atlantic-Mediterranean subregion, 6 species were chosen for the present study because of their relative abundance in the eastern Atlantic and Mediterranean area. Data are given on the variations in the number of radular tooth rows and their morphology for specimens at different developmental stages from juveniles to adults. Juvenile specimens smaller than $10 \mathrm{~mm}$ show a variable number of tooth rows which is always above 20 . In juvenile specimens larger than $10 \mathrm{~mm}$ in length or the juvenile pre-adult and adult stages, the number of tooth rows is invariably lower than 20 , but a positive linear relationship between body length and the number of tooth rows is still shown. The significance of this phenomenon is not known at this time, although different hypotheses have been suggested.
\end{abstract}

Key words: ontogenetic radular variation, Tambja, Polyceratidae, eastern Atlantic Ocean, Mediterranean Sea

RESUMEN: VARIACIÓN ONTOGENÉTICA DE LA RÁDULA DE LAS ESPECIES DEL GÉNERO TAMBJA BURN, 1962 (GASTROPODA, OPISTHOBRANCHIA, PolyCERATIDAE) DEL ESTE DEl OcÉANo AtLÁNTICO Y MAR MEDITERRÁNEO. - De las 10 especies del género Tambja (Polyceratidae) descritas en la subregión biogeográfica atlántico-mediterránea hemos seleccionado las 6 que lo han sido en la zona este del Océano Atlántico y en el Mediterráneo, para realizar un estudio ontogenético de la rádula de ejemplares en distintas fases de crecimiento. La recolección del material de estudio ha sido una tarea compleja dada la relativa abundancia de los ejemplares de estas especies, siendo especialmente laboriosa la recolección de ejemplares con una longitud menor de $10 \mathrm{~mm}$. Se ha correlacionado la longitud del animal con el número de filas de dientes en juveniles de muy pequeño tamaño, menores de $10 \mathrm{~mm}$, juveniles preadultos y adultos y se ha estudiado el cambio en la morfología de los dientes en las tres etapas de crecimiento. Destacamos que los juveniles de pequeño tamaño tienen un número de filas de dientes muy elevado, en todos los casos mayor de 20. Los juveniles preadultos y adultos siempre tienen una rádula con menos de 20 filas de dientes. En ejemplares de estas dos últimas fases de crecimiento existe una correlación lineal positiva entre la longitud del cuerpo del animal y el número de filas de dientes. El significado exacto del fenómeno descrito se desconoce por el momento, aunque se exponen distintas hipótesis que pueden dar respuesta al mismo.

Palabras clave: variación ontogenética radular, Tambja, Polyceratidae, este del Océano Atlántico, Mar Mediterráneo. 


\section{INTRODUCTION}

In general, the radular tooth rows of opisthobranchs increase in number with the size of the specimen up to the adult stage (Pruvot-Fol, 1926; Bertsch, 1976; Jensen, 1997). In Sacoglossa, the oldest teeth, the anterior radular teeth, differ in shape from the other teeth, and the radular teeth become larger as the animal grows (Jensen, 1997). Bertsch (1976), expanding on this idea, studied the radulae of 15 specimens of one species of opisthobranchs and collected data from the literature on different opisthobranch taxa, concluding that: a) the number of tooth rows increases with the length of the animal; b) the number of tooth rows depends on the total length of the radula; c) radulae with a higher maximum number of teeth in a half-row also have a greater number of tooth rows; and d) the tooth count per half-row is either stable or has a very narrow range of variation throughout the order or within a genus.

Bertsch (1978a, 1978b) studied the radulae of species of several genera of Chromodoridinae (Nudibranchia), highlighting the difference in the shape of the teeth between the radula of juveniles and adults. In contrast, Pruvot-Fol (1926) described the presence of pre-radula to distinguish the first tooth rows of the gastropod from the remaining rows during the juvenile stage. The shape of the teeth of the pre-radula may differ from that of the radula adult teeth. Focusing on the family Polyceratidae, Ferreira (1977), reported different radular patterns between juveniles and adults in species of the genus Triopha.

There is therefore data on the morphologic differences between the radula of juveniles and adults in opisthobranchs, the radula of the adults being particularly well-known. However, the few known data on juvenile radulae are usually based on samples that are at an advanced stage of growth and up to now there have been no data on the radulae of very small juveniles. This paper contributes radular data on 8 samples of between 3 and $8 \mathrm{~mm}$.

This study concentrates on the genus Tambja Burn, 1962 (Polyceratidae) from the coast of Granada and other Tambja species from southern Spain and the eastern Atlantic Ocean (the Atlantic-Mediterranean biogeographical subregion). The present paper provides data on the variation in number and morphology of tooth rows in individuals at different stages, studying radular changes from very small juvenile individuals $(3 \mathrm{~mm})$ to adults between 40 and $45 \mathrm{~mm}$. The radula of very young specimens of Tambja juveniles has a much greater number of rows than the radula of juvenile-pre-adults and adult individuals, although the exact significance of this is not known.

\section{MATERIAL AND METHODS}

The juvenile and adult Tambja species material used to measure body length and study the radula was collected primarily from the coast of Granada (southern Spain) and measured by us. Other material was collected at other points along the coast of Andalusia by malacologist colleagues and a third group of material comes from other studies. All of the samples were measured while alive, with the exception of ten preserved specimens.

The Mediterranean and eastern Atlantic species of the genus Tambja are relatively abundant. Collecting the Mediterranean specimens, especially the very small juveniles used for the present article, required great patience. The sampling work was repeated over four consecutive springs in order to provide the number of specimens presented here.

The material examined from Tambja ceutae García Gómez and Ortea, 1988 was collected from: the Isla de Tarifa (Cádiz) $\left(36^{\circ} 48^{\prime} \mathrm{N} 5^{\circ} 36^{\prime} \mathrm{W}\right)$, provided by Cesar Megina (one specimen, $35 \mathrm{~mm}$ long); Puerto de Adra (Almería) (36 $45^{\circ} \mathrm{N} 3^{\circ} 1^{\prime} \mathrm{W}$ ), provided by Diego Moreno (one specimen, $20 \mathrm{~mm}$ long); Guardias Viejas (Almería) (36 $41^{\circ} \mathrm{N}$ $2^{\circ} 50$ 'W), provided by Diego Moreno (one specimen, $40 \mathrm{~mm}$ long); Cantarriján (Almuñecar, Granada) (36 $44^{\prime} \mathrm{N} 3^{\circ} 46^{\prime} \mathrm{W}$ ), provided by Luis Sánchez-Tocino and Amelia Ocaña (one specimen, $10 \mathrm{~mm}$ long). Bibliographical data from living specimens were obtained from García Gómez and Ortea, 1988 (one specimen, $35 \mathrm{~mm}$ long). Data from preserved specimens of $T$. ceutae from the Canary Islands and Madeira in Caballer Gutiérrez et al, 2001 were also included.

The material examined from Tambja marbellensis Schick and Cervera, 1998 was collected from: Cantarriján (Almuñecar, Granada), provided by Luis Sánchez-Tocino and Amelia Ocaña (one specimen 12 $\mathrm{mm}$ long and three specimens, 3, 3 and $4 \mathrm{~mm}$ long respectively). Bibliographical data from living specimens was obtained from Schick and Cervera, 1998 (one specimen, $45 \mathrm{~mm}$ and another, $12 \mathrm{~mm}$ long).

The material examined from Tambja sp. was collected from Cantarriján (Almuñecar, Granada), provided by Luis Sánchez-Tocino and Amelia Ocaña: one specimen, $2 \mathrm{~mm}$ long; one specimen, $3 \mathrm{~mm}$ long; two specimens, 7 and $8 \mathrm{~mm}$ long respectively. 
TABLE 1. - Radular differences between living specimens of eastern Atlantic and Mediterranean species of Tambja.

\begin{tabular}{llcc}
\hline Species & References & Living specimens length (mm) & Radular formula \\
\hline T. fantasmalis & Ortea and García-Gómez (1986) & 20 & $13 \times 4.1 .1 .1 .4$ \\
T. ceutae & García-Gómez and Ortea (1988) & 35 & $15 \times 4.1 .1 .1 .4$ \\
T. ceutae & present paper & 20 & $12 \times 3-4.1 .1 .1 .3-4$ \\
T. ceutae & present paper & 40 & $19 \times 3-4.1 .1 .1 .3-4$ \\
T. ceutae & present paper & 10 & $28 \times 4.1 .1 .1 .4$ \\
T. ceutae & present paper & 35 & $16 \times 3-4.1 .1 .1 .3-4$ \\
T. anayana & Ortea (1989) & 6 & $28 \times 4.1 .1 .1 .4$ \\
T. simplex & Ortea and Moro (1999) & 45 & $18 \times 3-4.1 .1 .1 .3-4$ \\
T. simplex & Cervera et al. (2000) & 60 & $17 \times 4.1 .1 .1 .4$ \\
T. simplex & Cervera et al. (2000) & 40 & $20 \times 3-4.1 .1 .1 .3-4$ \\
T. marbellensis & Schick and Cervera (1998) & 12 & $13 \times 3-4.1 .1 .1 .3-4$ \\
T. marbellensis & Schick and Cervera (1998) & 45 & $16 \times 3-4.1 .1 .1 .3-4$ \\
T. marbellensis & present paper & 12 & $16 \times 4.1 .1 .1 .4$ \\
T. marbellensis & present paper & 3 & $29 \times 2-3.1 .1 .1 .2-3$ \\
T. marbellensis & present paper & 3 & $30 \times 2-4.1 .1 .1 .2-4$ \\
T. marbellensis & present paper & 4 & $30 \times 2-4.1 .1 .1 .2-4$ \\
Tambja sp. & present paper & 2 & $22 \times 2.1 .1 .1 .2$ \\
Tambja sp. & present paper & 3 & $36 \times 3.1 .1 .1 .3$ \\
Tambja sp. & present paper & 7 & $23 \times 4.1 .1 .1 .4$ \\
Tambja sp. & present paper & 7 & $25 \times 2-3.1 .1 .1 .2-3$ \\
Tambja sp. & present paper & 8 & $27 \times 3.1 .1 .1 .3$ \\
\hline
\end{tabular}

Given that only juvenile specimens of this species have been found, it has not been described as a new species. Sánchez-Tocino et al. (2000) described the species in detail and discussed it together with other Atlantic and Mediterranean species of the same genus.

Bibliographical data from living specimens of Tambja fantasmalis Ortea and García-Gómez, 1986 was obtained from their original description made from samples from eastern Atlantic waters. Tambja anayana Ortea, 1989 was obtained from his original description made from samples from eastern Atlantic waters, described from a presumably juvenile specimen of $6 \mathrm{~mm}$. Tambja simplex Ortea and Moro, 1998 was obtained from their original description made from samples from eastern Atlantic waters and data from Cervera et al. (2000) with living material from Cape Verde Archipelago.

We consider a "juvenile-pre-adult" individual to be an organism with an undeveloped reproductive system that is greater than $10 \mathrm{~mm}$ in total body length.

Statistical analysis was made with the Statistica 5.1 software (Statsoft) program, using a regression analysis (Fig. 1)

\section{RESULTS}

\section{Radular description}

The radular features of all the species from the eastern Atlantic-Mediterranean biogeographical subregion are listed in Table 1, including the specimen sizes and the radular formula in living specimens. The same data on $T$. ceutae from the Canary Islands and Madeira in Caballer Gutiérrez et al, 2001 are included in a separate table (Table 2), because these specimens are preserved.

These Tables provide data on the variation in the number of tooth rows in individuals at different stages.

Figure 1 shows drawings that illustrate the morphology of the rachidian, lateral and marginal teeth from samples of Tambja ceutae, T. marbellensis and Tambja sp. in different growth phases. Based on the material from these species and on bibliographical data on the morphology of the radulae of species found in the study area, it is possible to show that:

TABLE 2. - Radular differences between preserved Tambja ceutae specimens (data from Caballer Gutiérrez et al., 2001). We can assume that these specimens when living had a length roughly double that recorded after being preserved).

\begin{tabular}{lcc}
\hline $\begin{array}{l}\text { Preserved specimens } \\
\text { length }(\mathrm{mm})\end{array}$ & $\begin{array}{c}\text { Hypothetical correct } \\
\text { length }(\mathrm{mm}) \\
\text { (=preserved individual } \\
\text { length } \mathrm{x} \text { ) }\end{array}$ & Radular formula \\
\hline 28 & 56 & $19 \times 4.1 .1 .1 .4$ \\
23 & 46 & $18 \times 4.1 .1 .1 .4$ \\
23 & 46 & $15 \times 4.1 .1 .4$ \\
20 & 40 & $16 \times 4.1 .1 .1 .4$ \\
20 & 40 & $17 \times 4.1 .1 .4$ \\
20 & 40 & $13 \times 4.1 .1 .4$ \\
15.5 & 31 & $11 \times 4.1 .1 .1 .4$ \\
15 & 30 & $10 \times 4.1 .1 .1 .4$ \\
7 & 14 & $12 \times 4.1 .1 .4$ \\
6.5 & 13 &
\end{tabular}




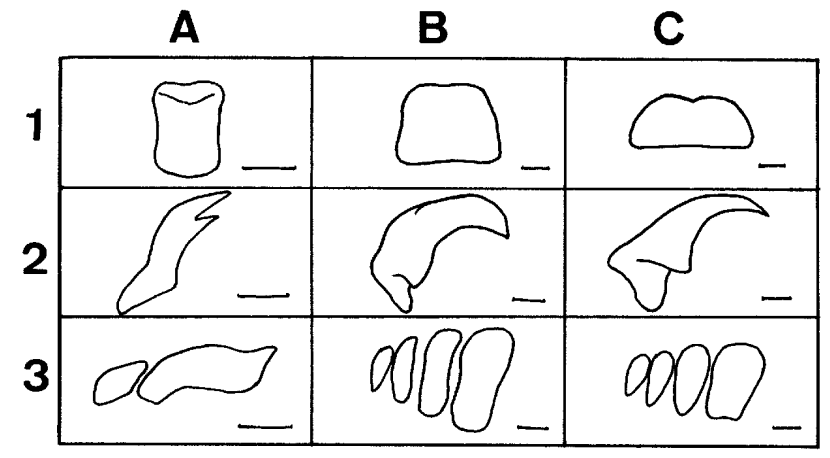

FIG. 1. - Drawings illustrating the morphology of the rachidian, lateral and marginal teeth in the different growth phases of different species of the genus Tambja found in southern Andalusia (Spain). Rachidian tooth from row $10,3 \mathrm{~mm}$ T. marbellensis (1A, scale 10 $\mu \mathrm{m})$; row $10,20 \mathrm{~mm}$ T. ceutae (1B, scale $100 \mu \mathrm{m})$; and row 6,40 $\mathrm{mm} T$. ceutae $(1 \mathrm{C}$, scale $100 \mu \mathrm{m})$. Lateral tooth from row $10,3 \mathrm{~mm}$ T. marbellensis (2A, scale $10 \mu \mathrm{m})$; row $10,20 \mathrm{~mm} \mathrm{~T}$. ceutae (2B, scale $100 \mu \mathrm{m})$; and row $6,40 \mathrm{~mm} \mathrm{~T}$. ceutae $(2 \mathrm{C}$, scale $100 \mu \mathrm{m})$. Marginal teeth from row $10,3 \mathrm{~mm}$ T. marbellensis (3A, scale 10 $\mu \mathrm{m})$; row 10, $20 \mathrm{~mm}$ T. ceutae (3B, scale $100 \mu \mathrm{m})$; and row 6,40 $\mathrm{mm}$ T. ceutae (3C, scale $100 \mu \mathrm{m})$.

The rachidian tooth of the juveniles less than 10 $\mathrm{mm}$ long is rectangular and taller than wide; in juvenile-pre-adults it tends to be quadrangular, almost as tall as wide, and weakly bilobed; in adults, the tooth becomes wider than tall and bilobed.

The lateral tooth has a slightly pronounced $\mathrm{C}$ or $\mathrm{S}$ shape and is the tooth that shows the greatest morphological variation in the different growth phases. It usually has an apical cusp and is frequently bifid in juveniles less than $10 \mathrm{~mm}$ long, tending to acquire a bump at the mid-basal level on its inside face as the animal grows and enters the juvenile-pre-adult and

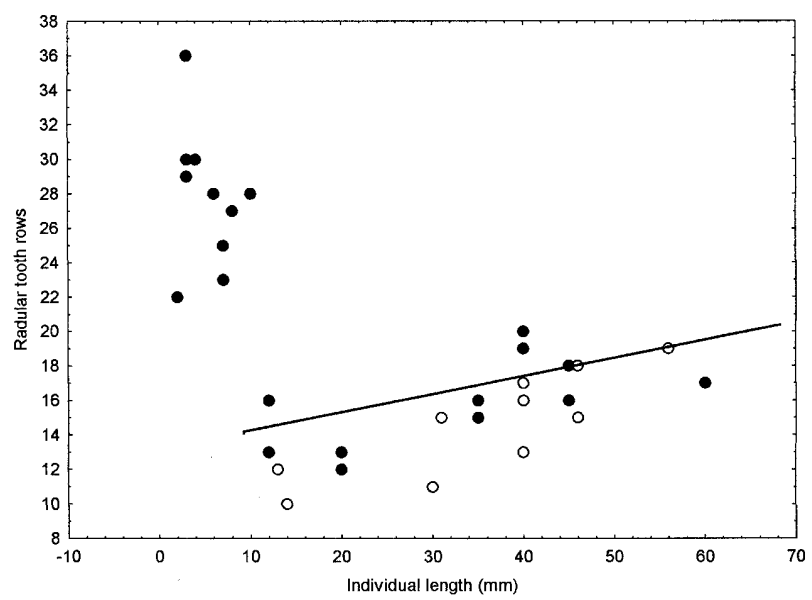

FIG. 2. - Relationship between the number of radular tooth rows and individual length of eastern Atlantic and Mediterranean Tambja species (based on Tables 1 and 2). Data with full circles refer to specimens whose body lengths have been measured when they are alive. Dependent variable: radular tooth rows; $\mathrm{R}^{2}=0.353 ; \mathrm{p}<$ 0.032 . Data with empty circles refer to specimens whose lengths have been measured after being preserved (data from Caballer Gutiérrez et al., 2001). adult stages. In more advanced stages of growth, the apex may be single or bifid according to the species. Additionally, the morphology varies within the same species and within the same growth stage of the animal from the back, younger part of the radulae to the front, older part.

The marginal teeth are rectangular, and markedly wider than tall in specimens less than $10 \mathrm{~mm}$ long. They have a tendency to become longer as the animals grow, such that they are almost quadrangular in juveniles at a more advanced stage of growth and taller than wide in the juvenile-pre-adult and adult stages. Additionally, the number of marginal teeth is greater in the younger tooth rows and when the animal acquires adult status.

This same variation pattern in the morphology of the radular teeth from the youngest individuals to the adults can also be confirmed, for example, in a juvenile-pre-adult, from the youngest part of the radulae to the oldest.

\section{Regression analysis between specimen length and number $\mathrm{OF}$ tooth rows}

The relationship between the length of the different specimens of the genus (21 living specimens and 10 preserved specimens) and the number of tooth rows in each case is shown in the regression analysis in Figure 2.

This graph clearly shows that the juvenile specimens less than $10 \mathrm{~mm}$ long vary in the number of tooth rows-which are consistently more than 20 - between 22 and 36 (the specimens with radula having more than 29 teeth rows were less than 4 $\mathrm{mm}$ long). When individuals reach $10 \mathrm{~mm}$ in length, although not yet adults (i.e. starting from a growth stage that we call juvenile pre-adult), the number of tooth rows decreases and from this growth stage they show a positive linear relationship between body length and number of tooth rows. Thus, there is a clear decrease in the number of tooth rows in the radula when the juvenile acquires a certain size. This is accompanied by the individual teeth becoming stronger. After they reach juvenile-pre-adult size, the number of tooth rows begins to increase, but not usually beyond 20 rows. In the juvenile size, the organisms have a significantly higher number of rows and it is therefore possible to see a distinct difference in the number of rows between juvenile, juvenile-pre-adult and adult members of the genus Tambja in the Mediterranean and eastern Atlantic Ocean. 


\section{DISCUSSION}

Regarding the morphology of the teeth, there are similarities between the morphology of the rachidian teeth in Figure 1 and the morphology of the rachidian teeth from a $6 \mathrm{~mm} T$. anayana sample in Ortea (1989), a $12 \mathrm{~mm} \mathrm{T.} \mathrm{marbellensis} \mathrm{sample} \mathrm{in}$ Schick and Cervera (1998), and a $35 \mathrm{~mm}$ adult from T. ceutae in García Gómez and Ortea (1988). The diagrams of the rachidian teeth from $T$. ceutae illustrated in Caballer et al. (2001) fit the general scheme of the morphologic evolution of this tooth since the $6.5 \mathrm{~mm}$ preserved sample was probably around 13 $\mathrm{mm}$ long when living and the $20 \mathrm{~mm}$ preserved sample was probably around $40 \mathrm{~mm}$ when living.

There are similarities between the diagrams of the marginal teeth in Figure 1 and the morphology of the marginal teeth from a $6 \mathrm{~mm} T$. anayana sample in Ortea (1989), a $12 \mathrm{~mm}$ T. marbellensis sample in Schick and Cervera (1998), and a $35 \mathrm{~mm} \mathrm{~T}$. ceutae adult sample in García Gómez and Ortea (1988).

Regarding the scant information that we have on nutrition, Nybakken and McDonald (1981) comment that bryozoans constitute the trophic base of the Tambja species, a hypothesis supported by our observations in this environment. In samplings along the coast of Granada during the spring time of the years 1997-2000, we found 8 juveniles less than $10 \mathrm{~mm}$ long, in all cases on the bryozoa Sessibugula barrosoi López de la Cuadra and García-Gómez, 1994, which leads us to think that this species must make up its nutritive base. There are no data on nutrition for Tambja adults found in the study area. Only Cervera et al. (2000) indicate that they found six specimens of $T$. simplex, 11-30 $\mathrm{mm}$ in length, collected at 10-35 m depth on bryozoans.

It is also important to note that the Tambja juveniles observed in southern Andalusia were always found underneath rocks and the adults have always been observed living on top of rocks. This suggests that while the juveniles and adults feed on bryozoans, they may eat different species.

We do not know whether the phenomenon described here of the juveniles less than $10 \mathrm{~mm}$ long having radulae with a high number of tooth rows as opposed to the juvenile-pre-adults and adults in the Tambja genus in the study area, which was also shown by Ferreira (1977) in the Triopha genus, can be extended to other Polyceridae or even perhaps to representatives of other Dorid families.

The significance of the phenomenon is also not known. Is it possible that the difference in the num- ber of tooth rows between very small juveniles and juvenile pre-adults and adults is due to a change in diet? Is it simply a consequence of the fact that juvenile radula are subject to more wear in the first stages of growth and that they have a greater capacity for forming radular teeth? Or is it simply some ancestral characteristic that is lost when the juvenile is preparing to become an adult?

\section{ACKNOWLEDGEMENTS}

We wish to express our gratitude to R. Morales for his constant help and assistance during the statistical analysis; to Diego Moreno and Cesar Megina for providing specimens; to Carlos $\mathrm{M}^{\mathrm{a}}$ de la Cuadra for help in identification and information on the bryozoans; and to Hans Bertsch and Lucas Cervera for their comments on previous versions of this manuscript. This work was partially supported by the CICYT PB98-1121 project.

\section{REFERENCES}

Bertsch, H. - 1976. Intraspecific and ontogenetic radular variation in opisthobranch systematics (Mollusca: Gastropoda). Syst. Zool., 25: 117-122.

Bertsch, H. - 1978 a. The Chromodoridinae Nudibranchs from the Pacific Coast of America. Part II. The Genus Chromodoris. Veliger, 20(4): 307-327.

Bertsch, H. -1978 b. The Chromodoridinae Nudibranchs from the Pacific Coast of America. Part III. The Genera Chromolaichma and Mexichromis. Veliger, 21(1): 70-86.

Caballer Gutiérrez, M., L. Moro Abad and J. Ortea Rato. - 2001. Nota sobre Tambja ceutae García Gómez and Ortea, 1988 (Mollusca, Opisthobranchia, Gymnodorididae) en las islas Canarias y Madeira. Vieraea, 29: 131-134.

Cervera, J.L., J.C. García-Gómez and R. Cattaneo-Vietti. - 2000. Additional data on the Phanerobranch Dorid Tambja simplex Ortea and Moro, 1998 (Gastropoda: Nudibranchia: Polyceratidae). Veliger, 43(2): 190-194.

Ferreira, A.J. - 1977. A review of the genus Triopha (Mollusca: Nudibranchia). Veliger, 19(4): 387-402.

García-Gómez, J.C. and J.A. Ortea. - 1988. Una nueva especie de Tambja Burn, 1962 (Mollusca, Nudibranchia). Bull. Mus. natn. Hist. nat., Paris $4{ }^{e ́}$ sér, 10, sect. A 2: 301-307.

Jensen, K.R. - 1997. Systematics, phylogeny and evolution of the Sacoglossa (Mollusca, Opisthobranchia). Vest. Forl., Denm. 94 pp.

Nybakken, J. and G. McDonald, 1981. Feeding mechanisms of west American nudibranchs feeding on Bryozoa, Cnidaria and Ascidiacea, with special respect to the radula. Malacología, 20(2): 439-449.

Ortea, J. - 1989. Descripción de una segunda especie de Tambja Burn, 1962 (Mollusca, Nudibranchia) de las islas de Cabo Verde. Publ. Ocas. Soc. Port. Malac., 14: 29-31.

Ortea, J. and J.C. García-Gómez. - 1986. Descripción de una nueva especie de Tambja Burn, 1962 (Mollusca: Nudibranchiata) del archipiélago de Cabo Verde. Publ. Ocas. Soc. Port. Malac., 7: 1-4.

Ortea, J. and L. Moro. - 1999. Descripción de tres Moluscos Opistobranquios nuevos de las islas de Cabo Verde. Avicennia, 8/9: $149-154$.

Pruvot-Fol, A. - 1926. Le bulbe buccal et la symétrie des Mollusques: I. La Radula. Arch. de Zool. Exp. et Gén., 65(5): 209-343, pl. 4-7. 
Sánchez-Tocino, L., F.J. García and Ocaña, A. - 2000 The genus Tambja Burn, 1962 (Gastropoda, Opisthobranchia) in the Mediterranean Sea with remarks on the intraspecific variability. Argonauta, 14(1): 67-75.

Schick, K.-L. and J.L. Cervera. - 1998. Description of a new species in the genus Tambja Burn, 1962 (Gastropoda: Nudibranchia: Polyceratidae) from Southern Spain. Veliger, 41(4) 344-350.

Scient. ed.: J.D. Ros 